\title{
Integrating cognitive and affective dimensions of pain experience into health professions education
}

\author{
Beth B Murinson MD PhD, Lina Mezei BS, Elizabeth Nenortas PhD
}

\begin{abstract}
BB Murinson, L Mezei, E Nenortas. Integrating cognitive and affective dimensions of pain experience into health professions education. Pain Res Manage 2011;16(6):421-426.

Pain is prevalent in clinical settings, and yet it is relatively under-represented in the education of most students in the health professions. Because pain includes both sensory-discriminative and affective features, teaching students about pain presents unique challenges and opportunities. The present article describes the evolution of a new blueprint for clinical excellence that, among other competencies, incorporates a need for the emotional development of clinical trainees. The framework has been applied to the development and implementation of two new courses in pain. The first course is designed to provide a comprehensive foundation of medical knowledge regarding pain, while integratively introducing students to the affective dimensions of pain. The second course is designed to enhance students' appreciation for the protean effects of pain through use of the humanities to represent medical experience. It is concluded that, to be most effective, fostering the emotional development of trainees in the health professions necessitates the incorporation of affect-focused learning objectives, educational tasks and assessment methods.
\end{abstract}

Key Words: Affect; Clinical skills; Content; Curriculum; Education; Empathy; Knowledge

That quick, glittering, empirical eye, sharp for the surface of things if for nothing beneath, he had not. But whether his apparent depth of vision was real, or only an artistic accident of corporeal moulding, nothing but his deeds could reveal. - Thomas Hardy, The Woodlanders (1887)

A present, the education system of the health professions provides only limited preparation in terms of cognitive tools to recognize and understand pain as a symptom of disease. To be most effective, new approaches to pain education must acknowledge the affective content of pain experience. The present article describes the evolution of a new blueprint that cultivates clinical excellence and guides the emotional development of medical students related to pain and its management. Examples discussed include the use of explicit mentoring, small groups with compassionate clinical experts, customized portfolios that are fully integrated into coursework and humanitiesbased materials with strong medical ties.

\section{THE SCOPE OF THE PROBLEM}

The experience of pain fundamentally incorporates both sensory-discriminative and affective features. For this reason, it is often deeply challenging to trainees in the health professions and seasoned clinicians alike (1). The so-called 'subjective nature of pain' means that clinical staff can become divided over the genuineness of a patient's pain, especially when the clinical picture is complicated by illicit drug use, psychiatric disease or personality disorder. At present, the education system for the health professions provides only limited preparation for clinicians in terms of cognitive tools to recognize and understand pain as a symptom of disease. This limited preparation does not anticipate the complications that arise when treating severe acute or chronic pain. To make matters worse, there is almost no preparation

\section{L'intégration des dimensions cognitives et affectives de l'expérience de la douleur à la formation dans les professions de la santé}

La douleur est prévalente en milieu clinique et pourtant, elle est relativement sous-représentée dans le cadre de la formation de la plupart des étudiants dans les professions de la santé. Puisque la douleur inclut à la fois des fonctions sensorielles-discriminatoires et des fonctions affectives, l'enseignement de la douleur aux étudiants présente des défis et des possibilités uniques. Le présent article décrit l'évolution d'un plan d'excellence clinique qui, entre autres compétences, intègre la nécessité d'assurer le développement affectif des apprenants. Ce cadre a été appliqué à l'élaboration et à la mise en œuvre de deux nouveaux cours sur la douleur. Le premier cours est conçu pour fournir des assises complètes de connaissances médicales au sujet de la douleur, tout en présentant peu à peu les dimensions affectives de la douleur aux étudiants. Le deuxième cours est conçu pour mieux faire comprendre aux étudiants les effets protéiformes de la douleur par l'utilisation des sciences humaines pour représenter l'expérience médicale. Il conclut que, pour maximiser l'efficacité du développement affectif des stagiaires dans les professions de la santé, il faut intégrer des objectifs d'apprentissage axés sur l'affect, des tâches éducationnelles et des méthodes d'évaluation.

in terms of addressing the affective dimensions of pain, and clinicians are often not able to aid patients deeply suffering with pain (2).

To be most effective, new approaches to pain education must acknowledge the affective content of pain experience. In fact, this is an area in which pain specialists can greatly contribute educational innovations for all health care practitioners by virtue of being able to lead important advances in emotional development. Historically, health care education has been strongly oriented to the development of an optimal medical database within the cognitive capacity of each practitioner, to the exclusion of building strong emotional skills (3). Evidence indicates that this is not sufficient for effective clinical care. Fortunately, there are trends for health professions schools to be more receptive to opportunities for shaping emotional development (4). Effective strategies include the following: explicit mentoring (5); small groups lead by compassionate clinical role models (6); customized portfolios that are fully integrated into coursework (7); and the use of humanities-based materials, with clear clinical relevance (8). The purpose of the present article is to describe an evolving framework for cultivating clinical excellence and the use of this framework to guide medical students in advancing to higher levels of emotional development vis-à-vis pain and its management.

\section{NEW BLUEPRINT FOR CLINICAL SKILLFULNESS} INCLUDES EMOTIONAL DEVELOPMENT

It is now widely recognized that clinical excellence is not a unidimensional phenomenon. Clinical excellence requires attainment of skill in multiple domains $(9,10)$. Although varying formulations of clinical competence have been advanced, it is necessary to identify models that are sufficiently adaptable to pertain to the wider range of clinical experience, especially pain. The model of Epstein and Hundert (10) is one such model that incorporates seven domains of clinical 
TABLE 1

Dimensions included in the Epstein and Hundert (10) model of professional development, and applications to teaching clinical pain care (in this example, applications are described that might pertain to a student learning about assessment, diagnosis and management of persistent headache)

\begin{tabular}{|c|c|}
\hline Dimension & Application \\
\hline Cognitive & $\begin{array}{l}\text { Name five antidepressants that are effective against } \\
\text { persistent pain. Describe the pain processing system } \\
\text { (nociceptive pathways) that signals pain in this region }\end{array}$ \\
\hline Emotional & $\begin{array}{l}\text { Recognize that pain can impact mood and acknowledge } \\
\text { the medical student's or physician's role in addressing } \\
\text { depressed mood. Accept that you may feel sad or } \\
\text { have other feelings after encountering a patient with } \\
\text { depressed mood related to pain }\end{array}$ \\
\hline Reflective & $\begin{array}{l}\text { Consider how your particular approach to a patient in } \\
\text { pain may have impacted the patient: did they feel } \\
\text { comforted or did they perceive that their concerns were } \\
\text { disregarded? }\end{array}$ \\
\hline Technical skills & $\begin{array}{l}\text { Query patients about the impact of pain on sleep, } \\
\text { function, enjoyment of life. Know how to gauge the } \\
\text { severity of effects in various domains and apply } \\
\text { appropriate instruments }\end{array}$ \\
\hline Values formation & $\begin{array}{l}\text { Adopt a nonjudgmental stance toward patients who } \\
\text { report severe pain even though acute trauma is not } \\
\text { apparent, and seek to restore function while obtaining } \\
\text { adequate analgesia }\end{array}$ \\
\hline Communication & $\begin{array}{l}\text { Ask a patient about the cardinal characteristics of their } \\
\text { pain, but also provide support and counseling where } \\
\text { appropriate. Exchange informational details as well as } \\
\text { conveying empathy and acting with compassion }\end{array}$ \\
\hline Clinical reasoning & $\begin{array}{l}\text { Formulate a differential diagnosis, identifying more and } \\
\text { less catastrophic diagnoses. Plan a diagnostic work-up } \\
\text { based on the history and physical examination }\end{array}$ \\
\hline
\end{tabular}

development. These include: cognitive, emotional and reflective development. This model also includes development in the domains of communication, values formation, technical skill and clinical reasoning (potentially categorized as a form of cognitive development) (11). Direct applications of this model can be made to learners at specific levels of training and areas of study; examples are shown in Table 1. Other models of clinical skillfulness described in medical literature emphasize 'relationship-centred' care (12), moral development (13), empathy (14), narrative medicine (15), nonverbal communication (16) and other approaches $(17,18)$. Each of these models seems to emphasize one or more aspects of the broader definitions of competence, and within those constraints offers valuable insights, eg, Roter's model emphasizes the role of nonverbal communication skills and emotion in the clinical encounter (16).

Clinical excellence in the area of pain management, in particular, demands attention to the domain of emotional development (19). This is because of the strong affective impact of pain, primarily on the person experiencing it directly, but also on those secondarily involved (20). Presently, relatively little is known about the emotional development of medical students (21). It has been suggested that the design of learning tasks appropriate to the socioemotional developmental stage of medical students is especially important (22). Unfortunately, medical schools have not been especially adept at or committed to incorporating emotion skills training into the regular curriculum (23). Recently, in an effort to understand better the normative emotional development of medical students, our group examined events occurring in medical school that were perceived by medical students as having an especially high impact (24) - the underlying assumption being that the perceived impact of an event depends, to a degree, on a student's stage of emotional development, as well as other factors.
Overall, the events identified as having the strongest impact were positive, perhaps reflecting the general positive outlook of students at the time of medical school graduation. Not surprisingly, students very strongly and consistently identified the encounter of exceptional role models as the event most likely to have a high impact (24). Students also identified several other events with more negative valence as having high impact. Among these events was seeing a patient in severe pain (24). We interpret this to mean that there are important gains to be made from providing better preparation for students in the area of pain medicine. Overall, the students varied widely in terms of the total impact that they ascribed to events in medical school. Our preliminary data analysis suggests that there may be observable differences between students destined for careers in surgery when compared with students going on to residency in internal medicine (unpublished data). The impact of affective predisposition and emotional sophistication on medical practice is an intriguing area of study that will likely yield improvements in clinical practice (1). More attention is needed to understanding the emotional needs of medical students (19) as well as the impact of skillful emotional response handling in various medical contexts (25).

\section{MATCHING LEARNING TASKS TO LEARNING ACTIVITIES: CULTIVATING INTELLECT AND AFFECT}

There is increasing concern that the traditional methods of preclinical education, eg, large lectures and laboratory experiences, are not ideally suited for long-term retention of relevant information. Widespread recognition of the need for improved educational strategies has led to the development of 'rational curriculum design' (26), nearly universal adoption of detailed learning objectives for educational process, and implementation of new assessment strategies (27). Certainly there is strong support for the idea that learning of technical skills occurs more robustly in a simulation-based environment (28). In addition, learning to apply new clinical knowledge through simulation practice in a supervised setting has been shown to be more effective than self-study or web-based instruction alone (29).

The incorporation of opportunities for emotional development in clinical training demands special attention because the ordinary methods of clinical education are ineffective in advancing the desired outcomes of increased empathy, compassion, and confidence in handling emotional challenges in clinical management (2). Studies indicate that current approaches to medical training have the effect of attenuating empathy (14). It seems the traditional educational methodologies are limiting the horizons of future health professionals in terms of reaching their potential for emotional development. Little is known about the processes that can be invoked to promote effective emotional development within a professional context. Some approaches that have been tried include intensive mentorship (13), Balint groups (30) and journaling (31).

During the clinical stages of training, the use of dynamic, small clinical teams is commonplace as medical education is incorporated into the workflow of hospital care delivery. The process of communication in these teams is complex and not intrinsically suited to providing subtle forms of feedback (5). Historically, the rounding team has been a learning environment that is characterized by sometimes fierce intellectual sparring (32). This type of environment may be distinctly counterproductive to cultivating compassionate responses (32). Even a more benign clinical experience led by a well-intentioned attending clinician may not result in appropriate emotional development, unless a fully explicit approach is used (5). Explicit disclosure of emotional experiences by the attending clinician make it possible for students to recognize emotional challenges as the seasoned clinician becomes aware of them, and to learn strategies for resolution as they are described aloud and demonstrated by the instructing clinician. Despite the many advantages intrinsic to the medical team approach, there are concerns that overemphasis on teamwork during training may interfere with a student's capacity for full empathic engagement with a patient and diffuse a student's sense of personal responsibility (33). 
TABLE 2

Portfolio activities and area of socioemotional development - selected examples and context in course

\begin{tabular}{|c|c|c|}
\hline Context & Area of development & Portfolio activity \\
\hline Introductory lecture & $\begin{array}{l}\text { Awareness of pain's impact and internality (subjectivity) of the } \\
\text { experience }\end{array}$ & Personal pain narrative \\
\hline Pain assessment small group & Awareness of pain in another, multidimensionality of pain & Description of pain using fine art image as a prompt \\
\hline Pain laboratory & $\begin{array}{l}\text { Awareness of pain being unpleasant, having cognitive effects } \\
\text { and having affective impact }\end{array}$ & Short, structured reflections on cold pressor experience \\
\hline $\begin{array}{l}\text { Pathophysiology lecture: } \\
\text { 'Mechanisms of persistent pain' }\end{array}$ & $\begin{array}{l}\text { Active engagement in material and self-discovery about areas } \\
\text { of interest }\end{array}$ & Personal learning objectives \\
\hline $\begin{array}{l}\text { Opioids and risk assessment for } \\
\text { abuse small group }\end{array}$ & $\begin{array}{l}\text { Acceptance of emotional reactions in highly charged situations, } \\
\text { recognition of adaptive strategies }\end{array}$ & $\begin{array}{l}\text { Pain and addiction: reactions to patients lying about abuse } \\
\text { and applications of new knowledge re pain processing after } \\
\text { chronic opioid exposure }\end{array}$ \\
\hline $\begin{array}{l}\text { Pain expert panel discussion of } \\
\text { acute pain management }\end{array}$ & $\begin{array}{l}\text { Acknowledgement of ideals and areas of inspiration in } \\
\text { medicine, acceptance of challenges }\end{array}$ & Personal qualities of pain providers and important lessons \\
\hline
\end{tabular}

Two approaches - the use of a structured portfolio, and the incorporation of humanities into the curriculum - show particular promise for engaging preclinical students in emotional development work and are discussed in detail below. One challenge that seems to persist is the introduction of this material in a manner that does not frustrate students and lead them to disregard this work as unimportant $(34,35)$. In the area of pain, the utility of recognizing, acknowledging and managing the affective content of a patient's experience is often recognizable to those with any past experience of serious pain. The more difficult challenge is motivating students who do not have a deeper appreciation for the impact of serious pain. Our previous work showed that $30 \%$ of medical students reported no personal or close family experience of serious pain (36). To some extent, these pain-naive students lacked the experiential framework needed to appreciate the highly disruptive nature of serious pain, to understand the profound affective impact of serious pain, and to refrain from drawing false analogies between pain in the medical context and other forms of psychosocial suffering, eg, heartache, social isolation or academic disappointment. None of these is an adequate representation of pain when confronted with a patient writhing in agony, whether from kidney stones, gout, migraine or other painful illness.

Most especially for these students, we designed a pain-lab experience. Delivered on the first day of our four-day pain course, the pain-lab experience involves all willing students undergoing a $30 \mathrm{~s}$ cold-pressor test. Students with Raynaud's syndrome and other cold-sensitive conditions are asked to refrain from immersing their hands. For this exercise, the students divide into groups of three. The three students rotate through positions of 'immerser' (person who is immersing their hand), timer (person who calls out time in $5 \mathrm{~s}$ intervals) and spotter (person who stands next to the 'immerser' and makes sure they are protected from serious harm if a vasovagal reaction occurs). The 'immerser' is instructed to hold the nondominant hand in ice water for $30 \mathrm{~s}$, while recording their pain scores every $5 \mathrm{~s}$ as announced by the timer. The 'immerser' is instructed that they may keep their pain scores private or share them with the others. The average level of pain experienced by the medical students was 6.7 on a 0 to 10 pain scale, as recorded at $30 \mathrm{~s}$. The students were asked to provide open and guided response reflections on the experience, and a number commented on the emotional distress associated with the immersion. Many students expressed surprise with the intensity of pain experienced, and several commented how difficult it would be to live life if this level of pain were ongoing. The cold-pressor immersion experience was believed to be very useful as part of the introduction to pain for these students.

\section{THE PORTFOLIO AS A TEACHING TOOL: OVERVIEW AND APPLICATIONS}

The portfolio, as a complement to regular clinical education, is a relatively new phenomenon. The earliest Medline reference to 'portfolio and medical students' dates to a 1994 article, describing the use of portfolio work to engage students in gaining a fuller knowledge and understanding of cancer. The students in that study collected records of interactions, events, relevant articles and other materials pertaining to their clinical training in following a patient with cancer (37). In recent years, the definition of what constitutes a portfolio has varied, but a recent review article defined the portfolio as one of two entities: a collection of materials that provides evidence of a student's learning activities and should include evidence of some intellectual processing of that material; or a learning journal with a collection of student reflections on learning (38). More generally, portfolios are found to be successful when certain criteria for implementation are met. These include clear instructions and expectations, robust integration with other course content, mentoring of the work, clear instructions that do not inhibit some freedom of expression and 'user-friendliness' that extends to making realistic demands on the students' time (7). We broadly defined a portfolio as a collection of student work reflecting engagement in medical learning extending beyond the accumulation of facts. A comprehensive portfolio will contain evidence of effort in multiple domains of professional competence: emotional development, reflective capacity, communications, technical skills and clinical reasoning may all be included. For our integrated pain course, we sought to develop a portfolio that would prompt students to experience, consider and reflect on the affective dimensions of pain and the implications of this for their lives as physicians.

The contents of the pain portfolio developed for our pain course were designed to be used in close parallel with the cognitively-oriented content of the course. In addition, we limited the activities to short exercises that could be completed in $5 \mathrm{~min}$ to $15 \mathrm{~min}$ while the students were in the classroom. The constraint from our medical school administration was that students were only to complete activities during classroom hours. Thus, $5 \mathrm{~min}$ to $10 \mathrm{~min}$ of in-class time for students to complete short activities in the portfolio were allotted. Several examples of portfolio activities are described in Table 2. As an example, the opening lecture about pain gave an abbreviated overview of pain prevalence, pain assessment, pain interventions and pain neurobiology. The lecture was limited to $45 \mathrm{~min}$, and students were asked to spend $10 \mathrm{~min}$ writing a short pain narrative, either in the first or second person. Students who had no previous experience of pain were asked to write discursively about pain. Surprisingly, only one or two students chose this option; the remainder wrote about personal pain experiences.

Two examples of how our conceptual model of cognitive and affective development was incorporated into portfolio design are provided here. In the first, a small group case discussion on pain and addiction was accompanied by a short reflective writing activity, asking students to anticipate what emotions they might feel the first time someone lies to them about the use of illicit substances (negativevalence task). This activity additionally asked the students to apply what they had learned about the effects of chronic opioid exposure on 
pain processing and how they might use their new knowledge of nonpharmacological treatments for pain to augment their treatment of these patients. This activity reflected an overall design strategy of encouraging students to reflect on affective responses, while anticipating how new knowledge about pain might be integrated into clinical practice, and how this knowledge might mitigate negative affective reactions toward patients with pain.

In the second example, a distinct but especially effective portfolio task was the reflection on personal qualities of pain-expert clinicians (one surgeon, one oncology fellow and one nurse-manager) that the students observed and queried during a pain management panel discussion. This was an affectively-oriented task designed to engage students in reflection on a positive-valence 'inspiring experience'. In this activity, the students were also asked about the most important questions and the most important lessons from the session. This aspect of the activity illustrates how we structured a link between more cognitivelyoriented observations and more affective/socioemotional reflections in order to help the students 'bridge the gap' between cognition and affect (39). This embedded structure endeavours to take advantage of the fact that affective responses are intrinsically highly motivating. In the case of the pain and addiction activity, we wanted students to recognize that frustration and disappointment can have a strong aversive effect on clinicians encountering pain in the context of substance abuse. This experience must be anticipated, acknowledged and even accepted as part of clinical practice. It should not interfere with the delivery of compassionate clinical care. Conversely, to reach their fullest potential, inspiring experiences, such as encountering exceptional role models, should also be reflected on and lead to explicit plans for improved clinical conduct.

\section{PAIN AND THE HUMANITIES AS AN EMOTIVE ENGINE}

Developing opportunities for fuller expression of medically-relevant emotional experiences, especially during the preclinical phases of training, is challenging. It requires a commitment to innovation and a willingness to expand the boundaries of ordinary approaches to medical education. There are multiple reports in the literature to suggest that the incorporation of humanities into medical and nursing curricula can be particularly effective at enhancing emotional awareness in students $(8,40,41)$. Nonetheless, debate persists about the utility of medical humanities $(42,43)$ and the applicable goals in the medical curriculum (35). For many years, regular education in the early phases of medical school has focused on fact-based learning and, indisputably, a strong cognitive underpinning is essential for competent clinical practice. Nonetheless, there is a challenge raised by the attenuation of empathy later in medical school and during postgraduate medical training. If self-reported empathy is very high early in medical school before extensive clinical exposures $(14,36)$, it is potentially an ideal time to prepare students to manage the pressures that they will experience.

Currently available evidence indicates that filling the curriculum with the facts of medicine may not be an adequate preparation for truly exceptional clinical conduct. We recently reported that $45 \%$ of graduating medical students experienced seeing a patient in severe pain as a high impact event in medical school (24). We hypothesize that students have strong memories of these pain experiences because they lack the tools to be more reflective, constructively critical and proactive. How do we best prepare students to render aid when a patient suffers severe pain from kidney stones or an acute appendicitis? What will the student do when rotating with a clinician who does not respond quickly to a patient's request for acute pain medication? What will that student do if they are in the room with a resident who refuses to return in $20 \mathrm{~min}$ to perform a dressing change, once the pre-emptive pain medication has started to work? How will that student feel? Will they recognize the inherent cruelty of ripping gauze from a granulating wound and side with the patient? Or will they identify with the harried resident who ignores or minimizes the suffering of the patient, perhaps casting aspersions at the ones who complain 'too much'? Even an extensive knowledge base about pain may not give the student appropriate tools to observe, process and intervene when they see a patient suffering.

The recognition that students need a framework to encounter, absorb and resolve to care about the suffering of patients with pain led to the creation of a new curriculum entitled 'Pain and the Humanities'. This course has been published online following peer review and is available free-of-charge from MedEdPortal (44). Designed to be delivered as four $2 \mathrm{~h}$ seminar sessions, the course has ambitious goals (summarized in Tables 3 and 4), which include the recognition of pain as an important part of many medical illnesses, and the observation that pain reflects both culture and context. The course is structured to give students the opportunity to observe and reflect on representations of pain within the fine arts. The students are engaged in pain experiences from several different perspectives, within different artistic media. This affords them greater pain appreciation and enables them to explore the subtleties of pain, as well as the opportunity to distinguish differences between psychic, existential and emotional forms of pain. Additionally, examining literary and artistic depictions of pain serves as an effective tool for understanding pain on a much more humane level, thereby aiding in the cultivation of more emotionally astute responses. Pain as captured in an artistic rendering can be very powerful, compelling the observers to try to begin to understand and relate to the different dimensions of despair within the sufferer. One especially potent example is the comparison of affective responses depicted in the 'Toothpuller', attributed to Caravaggio, compared with van Honthorst's representation of the same event (images obtained from Artstor using an institutional license). Painted a mere 20 years apart, the images could not be more different in the range of emotional responses shown by the dentist, the patient and the onlookers. Caravaggio depicts tooth-pulling as an intense struggle between an agonized, vulnerable patient, a fiercely determined dentist and luridly interested onlookers. van Honthorst's portrayal of the same clinical event evokes feelings of trust, compassion and empathy. Striking similarities in composition may be due to van Honthorst's keen interest in Caravaggio's work.

The sequencing of humanities content within a medical seminar course is very important. Our course begins with a unit on dramatic representations of pain. In this, the students are engaged in actively responding to pain brought to life before them, both critiquing the representations of others after watching a film clip, as well as participating in depicting pain themselves through dramatic reading or roleplay. The unit on pain literature follows, and is intended to aid the students in internalizing the pain experience and coming to the realization that they can appreciate the pain experience of another in some detail, even if they have not had that exact experience. Indeed, fascination with the human condition is a common link between literature and health care (45), with literature functioning to "capture the richness (and sometimes the poverty) of the human spirit" (46). The third session engages groups of two or three students in preparing a short presentation about a fine art work representing pain. This has the effect of honing their skills for observing evidence of pain and compels them to communicate what they see to their team members. Sometimes more impactful than the written word, artistic illustrations serve as graphic expressions that are better able to portray experiences that are overwhelming and often indescribable.

The seminar builds toward the final session on philosophic perspectives, which is intended to have the students integrate some of their experiences into a value-based philosophical framework and begin to idealize how they will use this new appreciation for pain: through a commitment to deliver high quality medical care for those in pain, or through a growing awareness of their personal pain-related values, or the simple but important recognition that people vary in the extent of valuing pain relief (but most people do value it). The overarching vision for the course was to engage the students in emotional development work vis-à-vis pain. Analysis of pain in the form of art evokes emotion, 
TABLE 3

Learning objectives in course on 'Pain and the Humanities'

\begin{tabular}{|c|c|c|c|}
\hline Session 1: Dramatic representation & Session 2: Literary descriptions & Session 3: Fine art depictions & Session 4: Philosophic perspectives \\
\hline $\begin{array}{l}\text { Pain is a feature of many common } \\
\text { diseases }\end{array}$ & $\begin{array}{l}\text { Pain is a key aspect of the illness } \\
\text { experience }\end{array}$ & $\begin{array}{l}\text { There is often, but not always, } \\
\text { observable evidence of serious pain }\end{array}$ & $\begin{array}{l}\text { People differ in the extent to which they } \\
\text { value the absence of pain }\end{array}$ \\
\hline $\begin{array}{l}\text { Pain has 'meaning'. This meaning is } \\
\text { influenced by context and culture }\end{array}$ & $\begin{array}{l}\text { The meaning of pain for patients is } \\
\text { individualized, depending on culture } \\
\text { and context }\end{array}$ & $\begin{array}{l}\text { Certain responses and actions make } \\
\text { pain more or less 'believable' }\end{array}$ & $\begin{array}{l}\text { Pain exists within culture and context, } \\
\text { sometimes linked to morality }\end{array}$ \\
\hline Pain is often described in vivid terms & $\begin{array}{l}\text { The suffering associated with pain is } \\
\text { dynamic and multidimensional }\end{array}$ & $\begin{array}{l}\text { Careful observation is crucial to } \\
\text { providing medical clues about pain }\end{array}$ & $\begin{array}{l}\text { Clinicians have a moral duty to relieve } \\
\text { pain }\end{array}$ \\
\hline $\begin{array}{l}\text { There are multiple kinds of pain and it } \\
\text { is important to distinguish them }\end{array}$ & $\begin{array}{l}\text { Mental (psychosocial) pain and } \\
\text { physical pain are different }\end{array}$ & $\begin{array}{l}\text { There is a range of typical responses to } \\
\text { pain }\end{array}$ & $\begin{array}{l}\text { Pain sensitivity is sometimes } \\
\text { intertwined with perceived character } \\
\text { strength }\end{array}$ \\
\hline $\begin{array}{l}\text { 'Others' have many different reactions } \\
\text { to pain; awareness of differences is } \\
\text { needed }\end{array}$ & $\begin{array}{l}\text { There are appropriate and } \\
\text { inappropriate responses to pain }\end{array}$ & $\begin{array}{l}\text { Doctors are in a unique position with } \\
\text { respect to the pain of others }\end{array}$ & $\begin{array}{l}\text { Clinicians need to be aware of their } \\
\text { pain-related values and acknowledge } \\
\text { those of their patients }\end{array}$ \\
\hline $\begin{array}{l}\text { Caring is expressed by others to those } \\
\text { in pain, the so-called 'humane } \\
\text { response' }\end{array}$ & $\begin{array}{l}\text { There is value in compassionate } \\
\text { responses to patients }\end{array}$ & $\begin{array}{l}\text { Empathetic awareness is necessary to } \\
\text { treat those in pain }\end{array}$ & $\begin{array}{l}\text { The development of compassionate } \\
\text { responses is appropriate and perhaps } \\
\text { essential }\end{array}$ \\
\hline
\end{tabular}

TABLE 4

Elements of a teaching plan in pain and the humanities (four sessions of $2 \mathrm{~h}$ each)

\begin{tabular}{|c|c|c|c|}
\hline Philosophy & Fine arts & Literature & Drama \\
\hline $\begin{array}{l}\text { Team-based learning about philosophy } \\
\text { dividing students into four philosophic } \\
\text { schools: Aristotelian, Stoic, Epicurean } \\
\text { and Utilitarian }\end{array}$ & $\begin{array}{l}\text { Student presentations of selected } \\
\text { artworks: Kahlo, Bosch, Caravaggio, } \\
\text { Dix and others. Leads to close } \\
\text { observation }\end{array}$ & $\begin{array}{l}\text { Poetry: Kahlil Gibran's 'On Pain', and a } \\
\text { discussion of the self-imposed nature } \\
\text { of pain (or not), and differences due } \\
\text { to culture }\end{array}$ & $\begin{array}{l}\text { Movie excerpt: First } 11 \text { min of 'Glory' } \\
\text { starring Broderick as a lightly } \\
\text { wounded soldier observing } \\
\text { unanesthetized leg amputation }\end{array}$ \\
\hline $\begin{array}{l}\text { Students work to answer detailed } \\
\text { questions on how their philosophic } \\
\text { school conceives of pain and then } \\
\text { solve a challenge question of clinical } \\
\text { management from their school's } \\
\text { perspective }\end{array}$ & $\begin{array}{l}\text { Guided observations and reflections on } \\
\text { the evidence of pain exhibited in } \\
\text { selected fine art works. Discussion of } \\
\text { neurobiology controlling pain } \\
\text { behaviour and what makes pain } \\
\text { 'believable' }\end{array}$ & $\begin{array}{l}\text { tephen King's pain } \\
\text { pact' to that of Doris } \\
\text { rth narrative in } \\
\text { ge' }\end{array}$ & $\begin{array}{l}\text { Dramatic reading of John Milton's } \\
\text { 'Samson agonists'. Samson is a man } \\
\text { with many kinds of emotional } \\
\text { degradation but little physical pain: } \\
\text { important contrasts to physical pain } \\
\text { here }\end{array}$ \\
\hline $\begin{array}{l}\text { Lecture presentation of philosophic } \\
\text { perspectives holds the promise of } \\
\text { great breadth but is not interesting to } \\
\text { all students }\end{array}$ & $\begin{array}{l}\text { Crucifixion scenes offer a longitudinal } \\
\text { and multicultural series of pain } \\
\text { images but are heavily laden with } \\
\text { potent cultural messages }\end{array}$ & $\begin{array}{l}\text { Poetry alternative: Haiku of Basho and } \\
\text { Issa has imagery of winter, dry bones, } \\
\text { snails crying in the frying pan, a worm } \\
\text { eating a chestnut }\end{array}$ & $\begin{array}{l}\text { Role play where students adopt the } \\
\text { roles of patients with specific pain- } \\
\text { illness or the role of interns; prompts } \\
\text { awareness of pain in diagnosis }\end{array}$ \\
\hline
\end{tabular}

promotes contemplation and introspection and, in turn, fosters emotional growth $(44,45,47,48)$. Preliminary data indicate that the essays that the students produce in the course demonstrate a serious effort to perceive and acknowledge the affective content of pain experience.

\section{SYNOPSIS}

It is the experience of many that physicians are not always prepared to attend to and address medical conditions in which pain predominates. Clearly, there is a need for physicians to be prepared in this area, most especially because pain is a feature of many clinical encounters (49). However, relatively little time is spent learning about pain in medical school.

Innovative approaches are needed to improve the training of health care providers in the area of pain. To be most effective, the approaches taken need to acknowledge the affective content of pain experience - to do otherwise leads to frustration and disappointment. In truth, we can be most helpful to our colleagues involved in the general education of the health professions if we adopt the stance of being able to do important work in the area of emotional development, by virtue of the emotional impact of pain. Fact-intensive curricula are necessary but not sufficient, and new methods of teaching in medical schools are rich in opportunities to shape emotional development. These methods include explicit mentoring, small groups with compassionate clinical experts, customized portfolios that are fully integrated into coursework and the use of humanities-based materials with strong medical ties. Attention to the emotional development of health professions students is sorely needed. We know how to fill smart young people with medical facts, but we now need to discover how to fill them with the emotional strength to accomplish great and compassionate care.

ACKNOWLEDGEMENTS: This work was supported, in part, by grants from the Mayday Fund and the Milbank Foundation for Rehabilitation Research.

\section{REFERENCES}

1. Verheul W, Sanders A, Bensing J. The effects of physicians' affectoriented communication style and raising expectations on analogue patients' anxiety, affect and expectancies. Patient Educ Couns 2010;80:300-6.

2. Coulehan J. Viewpoint: Today's professionalism: Engaging the mind but not the heart. Acad Med 2005;80:892-8.

3. Posen S. The portrayal of the physician in non-medical literature. Resentment, confrontation, litigation. J R Soc Med 1992;85:520-3.

4. Suchman AL, Williamson PR, Litzelman DK, et al. RelationshipCentered Care Initiative Discovery Team. Toward an informal curriculum that teaches professionalism. Transforming the social environment of a medical school. J Gen Intern Med 2004;19:501-4.

5. Burack JH, Irby DM, Carline JD, Root RK, Larson EB. Teaching compassion and respect. Attending physicians' responses to problematic behaviors. J Gen Intern Med 1999;14:49-55.

6. Wright SM, Kern DE, Kolodner K, et al. Attributes of excellent attending-physician role models. N Engl J Med 1998;339:1986-93. 
7. Driessen E, van Tartwijk J, van der Vleuten C, Wass V. Portfolios in medical education: why do they meet with mixed success? A systematic review. Med Educ 2007;41:1224-33.

8. Marnocha S, Marnocha M. Windows open: Humanities teaching during undergraduate clinical experiences. J Nurs Educ 2007;46:517-21.

9. Baig L, Violato C, Crutcher R. A construct validity study of clinical competence: A multitrait multimethod matrix approach. J Contin Educ Health Prof 2010;30:19-25.

10. Epstein RM, Hundert EM. Defining and assessing professional competence. JAMA 2002;287:226-35.

11. Bordage G. Elaborated knowledge: A key to successful diagnostic thinking. Acad Med 1994;69:883-5.

12. Beach MC, Inui T. Relationship-centered care: A constructive reframing. J Gen Intern Med 2006;21(Suppl 1):S3-8.

13. Branch Jr WT. The road to professionalism: reflective practice and reflective learning. Patient Educ Couns 2010;80:327-32.

14. Hojat M, Gonnella JS, Mangione S, et al. Empathy in medical students as related to academic performance, clinical competence and gender. Med Educ 2002;36:522-7.

15. Charon R. The patient-physician relationship: Narrative medicine: A model for empathy, reflection, profession, and trust. JAMA 2001;286:1897-902.

16. Roter DL, Frankel RM, Hall JA, Sluyter D. The expression of emotion through nonverbal behavior in medical visits. Mechanisms and outcomes. J Gen Intern Med 2006;21(Suppl 1):S28-34.

17. Satterfield JM, Hughes E. Emotion skills training for medical students: A systematic review. Med Educ 2007;41:935-41.

18. Hilton SR, Slotnick HB. Proto-professionalism: How professionalisation occurs across the continuum of medical education. Med Educ 2005;39:58-65.

19. Murinson BB, Agarwal AK, Haythornthwaite JA. Cognitive expertise, emotional development, and reflective capacity: Clinical skills for improved pain care. J Pain 2008;9:975-83.

20. Monin JK, Schulz R, Martire LM, et al. Spouses' cardiovascular reactivity to their partners' suffering. J Gerontol B Psychol Sci Soc Sci 2010;65B:195-201.

21. Rosenthal JM, Okie S. White coat, mood indigo - depression in medical school. N Engl J Med 2005;353:1085.

22. Reis SP, Wald HS, Monroe AD, Borkan JM. Begin the BEGAN (The Brown Educational Guide to the Analysis of Narrative) a framework for enhancing educational impact of faculty feedback to students' reflective writing. Patient Educ Couns 2010;80:253-9.

23. Flowers LK. The missing curriculum: Experience with emotional competence education and training for premedical and medical students. J Natl Med Assoc 2005;97:1280-7.

24. Murinson BB, Klick B, Haythornthwaite JA, et al. Formative experiences of emerging physicians: gauging the impact of events that occur during medical school. Acad Med 2010;85:1331-7.

25. Gross R, Brammli-Greenberg S, Tabenkin H, Benbassat J. Primary care physicians' discussion of emotional distress and patient satisfaction. Int J Psychiatry Med 2007;37:331-45.

26. Kern DE, Thomas PA, Hughes MT. Curriculum Development for Medical Education: A Six-Step Approach, 2nd edn. Baltimore: The Johns Hopkins University Press, 2009.

27. Norman G, Neville A, Blake JM, Mueller B. Assessment steers learning down the right road: Impact of progress testing on licensing examination performance. Med Teach 2010;32:496-9.

28. Issenberg SB, McGaghie WC, Petrusa ER, et al. Features and uses of high-fidelity medical simulations that lead to effective learning: A BEME systematic review. Med Teach 2005;27:10-28.

29. Sholomskas DE, Syracuse-Siewert G, Rounsaville BJ, et al. We don't train in vain: A dissemination trial of three strategies of training clinicians in cognitive-behavioral therapy.

J Consult Clin Psych 2005;73:106-15.

30. Novack DH, Suchman AL, Clark W, et al. Calibrating the physician: Personal awareness and effective patient care. JAMA 1997;278:502-9.

31. Levine RB, Kern DE, Wright SM. The impact of prompted narrative writing during internship on reflective practice: A qualitative study. Adv Health Sci Educ Theory Pract 2008;13:723-33.

32. Silver HK, Glicken AD. Medical student abuse: incidence, severity, and significance. JAMA 1990;263:527-32.

33. Spiro H. Empathy: An introduction. In: Spiro H, McCrea Curnen MG, Peschel E, St James D, eds. Empathy and the Practice of Medicine: Beyond Pills and the Scalpel. New Haven: Yale University Press, 1996.

34. Thernstrom, M. The writing cure. In: Carr DB, Loeser JD, Morris DB, eds. Narrative, Pain and Suffering, Progress in Pain Research and Management. Volume 34. Seattle: IASP Press, 2005.

35. Shapiro J, Coulehan J, Wear D, et al. Medical humanities and their discontents: Definitions, critiques, and implications. Acad Med 2009;84:192-8.

36. Murinson BB, Agarwal AK, Klick D, et al. Underestimation of pain by medical students is associated with negative emotional reactions to pain. J Pain 2007;8:S84.

37. Finlay IG, Maughan TS, Webster DJ. Portfolio learning: A proposal for undergraduate cancer teaching. Med Educ 1994;28:79-82.

38. Ross S, Maclachlan A, Cleland J. Students' attitudes towards the introduction of a Personal and Professional Development portfolio: Potential barriers and facilitators. BMC Med Educ 2009;9:69.

39. Fischer KW, Bidell TR. Dynamic development of action, thought and emotion. In: Damon W, Lerner RM, eds. Theoretical Models of Human Development. Handbook of Child Psychology, 6th edn. New York: Wiley, 2006.

40. Bardes CL, Gillers D, Herman AE. Learning to look: Developing clinical observational skills at an art museum. Med Educ 2001;35:1157-61.

41. Shapiro J, Rucker L, Beck J. Training the clinical eye and mind: Using the arts to develop medical students' observational and pattern recognition skills. Med Educ 2006;40:263-8.

42. Ousager J, Johannessen H. Humanities in undergraduate medical education: A literature review. Acad Med 2010;85:988-98.

43. Schwartz AW, Abramson JS, Wojnowich I, et al. Evaluating the impact of the humanities in medical education. Mt Sinai J Med 2009;76:372-80.

44. Murinson BB. Pain and the Humanities: Exploring the Meaning of Pain in Medicine Through Drama, Literature, Fine Arts and Philosophy. MedEdPORTAL. <http://services.aamc.org/30/ mededportal $/$ servlet $/ \mathrm{s} /$ segment $/$ mededportal $/$ ?subid $=8129>$. (Accessed on August 1, 2011).

45. Donohoe M, Danielson S. A community-based approach to the medical humanities. Med Educ 2004;38:204-17.

46. Daniel SL. Literature and medicine: In quest of method. Liter Med 1987;6:1-11.

47. Davis C. Nursing humanities: The time has come. Am J Nurs 2003;103:13.

48. Koithan M. Aesthetics in nursing practice and education. Iss Mental Health Nurs 1996;17:529-39.

49. Sullivan MD, Edlund MJ, Fan MY, et al. Trends in use of opioids for non-cancer pain conditions 2000-2005 in commercial and Medicaid insurance plans: The TROUP study. Pain 2008;138:440-9. 


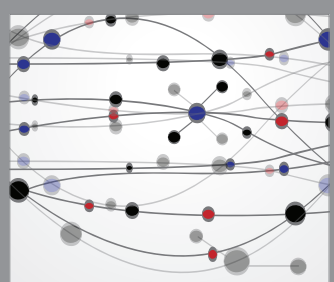

The Scientific World Journal
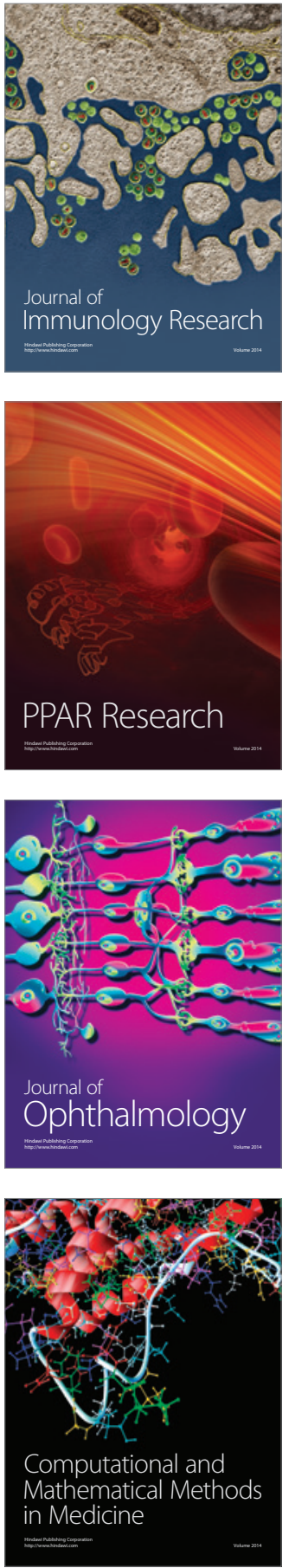

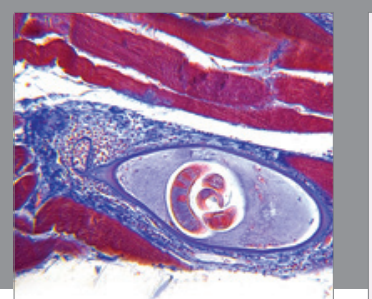

Gastroenterology Research and Practice

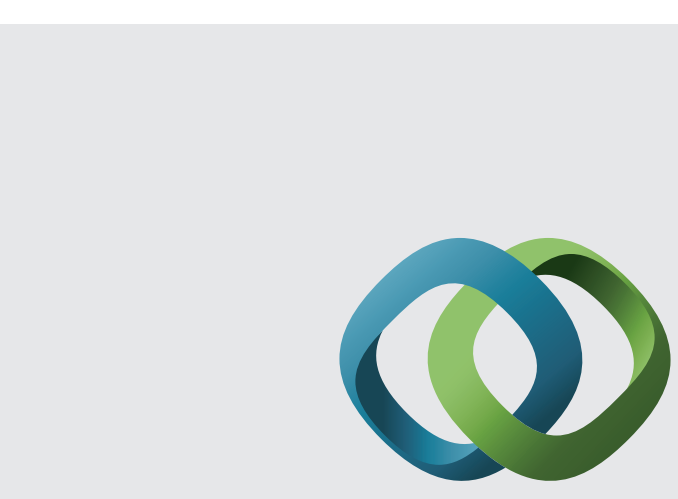

\section{Hindawi}

Submit your manuscripts at

http://www.hindawi.com
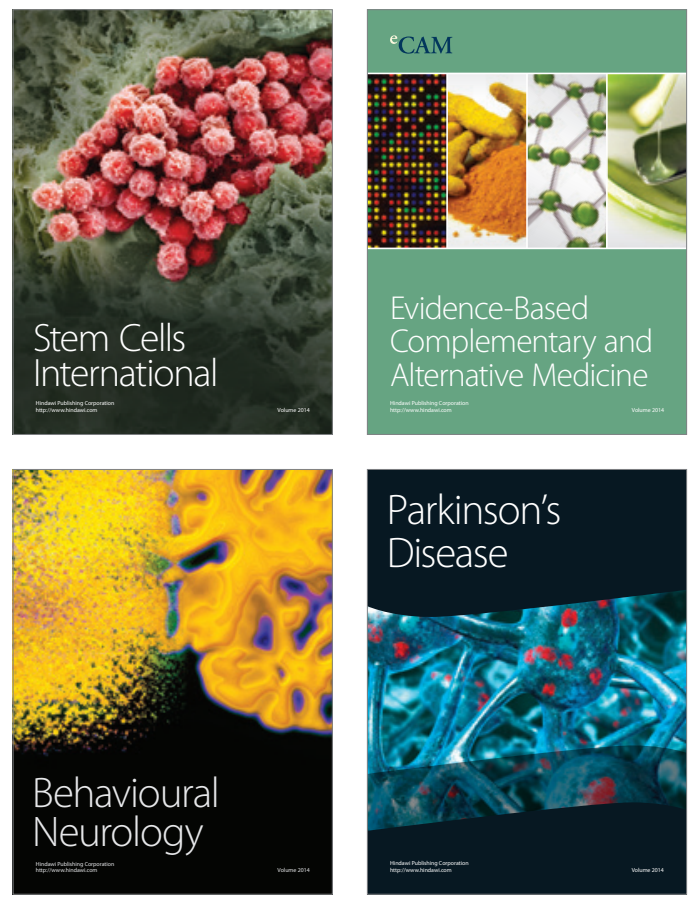
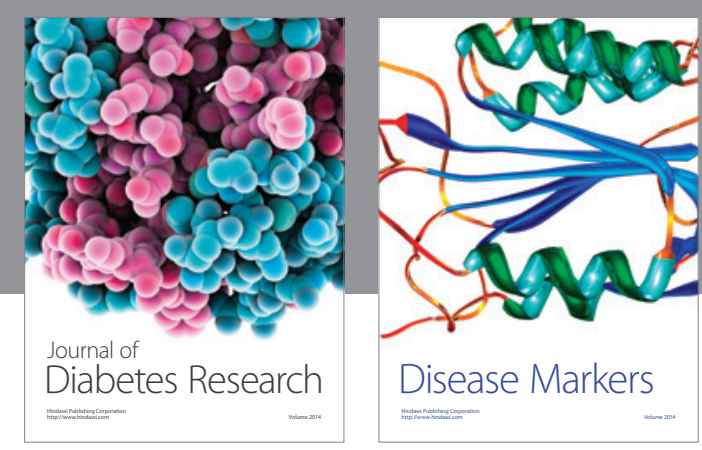

Disease Markers
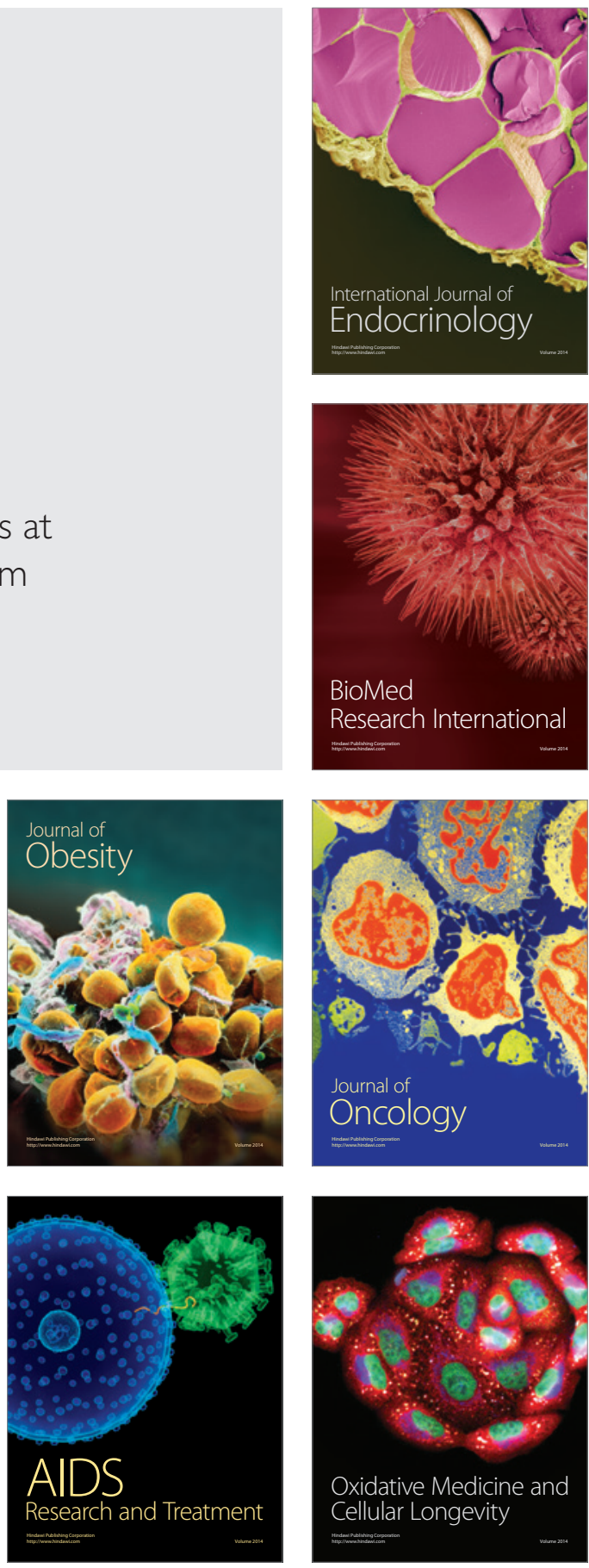